\title{
ANALISIS STRUKTUR STASIUN MRT (MASS RAPID TRANSIT) BLOK M TERHADAP KETAHANAN GEMPA \\ (Studi Kasus : Stasiun MRT Blok M Jakarta Selatan)
}

\author{
(Structure Analysis Of Mass Rapid Transit Blok M Station For Earthquake Resistance) \\ (Case Study: MRT Bridge CP 103))
}

\author{
Bahri Wahabi $^{1}$, F.X. Ferry Munaf ${ }^{1}$, Fadli Kurnia $^{1}$ \\ ${ }^{1}$ Program Studi Teknik Sipil Fakultas Teknik Universitas Pancasila \\ E-mail: bahriwahabi@gmail.com
}

\begin{abstract}
ABSTRAK
MRT Jakarta ( Mass Rapid Transit ) Adalah sebuah moda transportasi transit tercepat menggunakan kereta rel listrik yang dibangun di Jakarta dalam memajukan infrastruktur yang terintegrasi dan demi pemerataan transportasi diseluruh Indonesia. Dengan berbagai macam zona gempa di Indonesia maka stasiun MRT Blok M sebagai acuan untuk membangun stasiun lain di zona gempa yang berbeda. Berdasarkan paparan di atas, maka penelitian ini dilakukan untuk mengevaluasi bangunan struktur sehingga bisa sebagai acuan pembuatan stasiun MRT lainnya yang dengan spesifikasi yang sama, menganalisis kekuatan struktur (respons struktur) dari stasiun MRT Blok M, menganalisis kekuatan struktur berdasarkan gempa maksimum dan gempa minimum di Indonesia berdasarkan SNI 1726 2016. Dengan permodelan bantuan CSI Bridge V 20. Analisis ini membandingkan stasiun MRT dengan Respons Spektrum gempa rendah, Respons spektrum gempa tinggi , dan Respons spektrum gempa sedang . Sehingga di dapatkan momen maksimum untuk gempa tinggi 1334,8717 Ton-m, momen maksimum untuk gempa rendah 1179,4592 Ton-m, momen maksimum untuk gempa sedang 1256,9908 Ton-m. dan untuk gaya geser untuk gempa tinggi 507,8314 ton , untuk gempa rendah 505,0548 Ton, dan untuk gaya geser gempa sedang 506,4403 Ton . Displacement maksimum untuk permodelan gempa sedang $-3,17 \mathrm{~mm}$ ke arah $\mathrm{z}$, gempa skala rendah $-2,48 \mathrm{~mm}$ ke arah z, gempa tinggi -3,21 mm ke arah z. untuk nilai defleksi maksimum 60,903 mm dengan gempa skala tinggi ,untuk nilai koefisien stabilitas maksimum akibat defleksi yaitu 0,025rad. Dalam analisis ini mengevaluasi tentang momen, gaya geser, displacement, simpangan antar lantai , koefisien stabilitas . dengan perbandingan antar gempa lemah dan gempa tinggi serta gempa eksisting
\end{abstract}

Kata Kunci: Respons Spektrum, Gempa, Stasiun MRT

\begin{abstract}
Jakarta MRT (Mass Rapid Transit) Is the fastest transit mode using an electric railroad built in Jakarta to promote integrated infrastructure and for the sake of equitable transportation throughout Indonesia. With various kinds of earthquake zones in Indonesia, the Blok M MRT station is a reference for building other stations in different earthquake zones. Based on the above explanation, this study was conducted to evaluate the structure of the building so that it can be used as a reference for making other MRT stations with the same specifications, analyzing the structural strength (structural response) of the Blok M MRT station, analyzing the strength of the structure based on the maximum earthquake and minimum earthquake in Indonesia is based on SNI 17262016 . With the modeling of the assistance of CSI Bridge V 20. This analysis compares the MRT station with the low earthquake spectrum response, the response of the high earthquake spectrum, and the response of the moderate earthquake spectrum. So that you get the maximum moment for a high earthquake of 1334.8717 Ton- $m$, the maximum moment for a low earthquake is 1179.4592 Ton-m, the maximum moment for an earthquake is 1256,9908 Ton-m. and for shear forces for high earthquakes 507.8314 tons, for low earthquakes 505.0548 tons, and for moderate earthquake shear 506.4403 tons. The maximum displacement for moderate earthquake modeling is $-3.17 \mathrm{~mm}$ towards $z$, low-scale earthquake is -2.48 $\mathrm{mm}$ in the direction of $\mathrm{z}$, high earthquake is $-3.21 \mathrm{~mm}$ in the direction of $\mathrm{z}$. for a maximum deflection value of 60.903 $\mathrm{mm}$ with a high-scale earthquake, for the maximum stability coefficient due to deflection of 0.025rad. In this analysis evaluate the moment, shear force, displacement, intersection between floors, stability coefficient. with a comparison between weak earthquakes and high earthquakes and existing earthquakes
\end{abstract}

Keywords: Spectrum Response, Earthquake, MRT Station. 


\section{PENDAHULUAN}

MRT Jakarta dibangun untuk memajukan infrastruktur yang terintegrasi di Indonesia dan demi pemerataan transportasi diseluruh Indonesia. Sehingga masyarakat diseluruh Indonesia bisa merasakan dan memiliki moda transportasi yang terintegrasi. Sehingga transportasi Indonesia bisa mengejar dan menyaingi Negara lain seperti Singapura, Malaysia dan Jepang.

Indonesia merupakan daerah rawan gempa bumi karena dilalui oleh jalur pertemuan 3 lempeng tektonik, yaitu: lempeng Indo-Australia, lempeng Eurasia, dan lempeng Pasifik. Lempeng Indo-Australia bergerak relatif ke arah utara dan menyusup ke dalam lempeng Eurasia, sementara lempeng Pasifik bergerak relatif ke arah barat. Kegiatan tektonik ini membentuk zona sumber gempa (seismic zones), berupa lajur tujaman (subduction zones), lajur sesar tegak membuka (transtensional zones) dan lajur sesar (thrust zones) disebagian besar kawasan Indonesia. Lajur-lajur ini bercirikan pergeseran kerak bumi, yang selalu menimbulkan gempa bumi tektonik. Menurut SNI 031726-2012,

Maksud dari penelitian ini adalah memberi masukan kepada instansi terkait yaitu Kementrian Perhubungan (Direktorat Jendral Perkeretaapian) dan PT MRT Jakarta serta PT Kereta Api untuk Redesain struktur pada stasiun Blok M Jakarta Selatan sehingga bisa digunakan di seluruh Indonesia. Sedangkan tujuan dari penelitian ini adalah untuk:

1. Mengevaluasi bangunan struktur sehingga bisa dijadikan sebagai pembanding dengan struktur eksisting

2. Mengenganalisis kekuatan struktur dari Stasiun MRT Blok M .

3. Menganalisis kekuatan struktur berdasarkan gempa maksimum dan gempa minimum di indonesia.

\section{TINJAUAN PUSTAKA}

\section{Struktur Jembatan}

Jembatan mempunyai arti penting bagi setiap orang akan tetapi tingkat kepentingannya tidak sama bagii setiap orang, sehingga akan menjadi suatu bahan studi yang menarik. Suatu jembatan tunggal diatas sungai kecil akan dipandang berbeda oleh tiap orang, sebab pengelihatan/ pandangan masing masing orang saat pergi bekerja hanya dapat melintasi jembatan setiap hari pada saat pergi bekerja, hanya dapat melintasi sungai bila ada jembatan setiap hari pada saat pergi bekerja hanya dapat melintasi sungai bila ada jembatan dan ia menyatakan bahwa jembatan adalah sebuah jalan yang diberi sandaran pada tepinya. Tentu bagi seorang pempin pemerintahan dan dunia bisnis akan memandang hal yang berbeda pula

\section{Magnitude}

Magnitude adalah suatu besaran yang menggambarkan besarnya regangan energi yang dilepaskan waktu terjadinya gempa bumi. Ada beberapa rumusan untuk mencari magnitude ini, yang paling umum digunakan adalah definisi magnitude yang diberikan oleh Richter.

Tabel 1 Magnitude dan kelas kekuatan gempa

\begin{tabular}{|c|c|c|c|}
\hline $\begin{array}{c}\text { Magnitude } \\
\text { Gempa }\end{array}$ & $\begin{array}{c}\text { Kelas } \\
\text { Kekuatan } \\
\text { Gempa }\end{array}$ & $\begin{array}{c}\text { Pengaruh } \\
\text { Gempa }\end{array}$ & $\begin{array}{l}\text { Perkiraan } \\
\text { Kejadian } \\
\text { Pertahun }\end{array}$ \\
\hline$<2,5$ & Gempa kecil & $\begin{array}{l}\text { Pada umumnya } \\
\text { tidak dirasakan, } \\
\text { tetapi dapat } \\
\text { direkam oleh } \\
\text { seismograf }\end{array}$ & 900.000 \\
\hline 2,5 s/d 4,9 & Gempa kecil & $\begin{array}{c}\text { Selalu dapar } \\
\text { dirasakan, tetapi } \\
\text { hanya dapat } \\
\text { menyebabkan } \\
\text { kerusakan kecil }\end{array}$ & 30.000 \\
\hline 5,0 s/d 5,9 & $\begin{array}{l}\text { Gempa } \\
\text { sedang }\end{array}$ & $\begin{array}{c}\text { Menyebabkan } \\
\text { kerusakan pada } \\
\text { bangunan dan } \\
\text { struktur-struktur } \\
\text { yang lain }\end{array}$ & 500 \\
\hline 6,0 s/d 6,9 & $\begin{array}{l}\text { Gempa } \\
\text { Sedang }\end{array}$ & $\begin{array}{l}\text { Kemungkinan } \\
\text { dapat } \\
\text { menyebabkan } \\
\text { kerusakan besar, } \\
\text { pada daerah } \\
\text { dengan populasi } \\
\text { tinggi }\end{array}$ & 100 \\
\hline 7,0 s/d 7,9 & $\begin{array}{l}\text { Gempa } \\
\text { Besar }\end{array}$ & $\begin{array}{c}\text { Menimbulkan } \\
\text { kerusakan yang } \\
\text { serius }\end{array}$ & 20 \\
\hline$\geq 8,0$ & $\begin{array}{l}\text { Gempa } \\
\text { Besar }\end{array}$ & $\begin{array}{c}\text { Dapat } \\
\text { menghancurlebur } \\
\text { kan daerah yang } \\
\text { dekat dengan } \\
\text { pusat gempa }\end{array}$ & $\begin{array}{c}\text { Satu } \\
\text { setiap } \\
\text { 5-10 tahun }\end{array}$ \\
\hline
\end{tabular}

(Sumber : Chen (2000))

\section{Defleksi}

Defleksi atau simpangan antar lantai harus dihitung sebagai perbedaan defleksi pada pusat massa jembatan yang ditinjau. adapun cara menghitung defleksi pada pusat massa $\delta$ sesuai persamaan berikut :

$$
\delta=\frac{C_{d} \delta_{x e}}{I_{e}}
$$

\section{Pengaruh P-A}

Setiap bangunan baik gedung maupun non gedung memiliki pengaruh $\mathrm{P}-\Delta$ pada geser dan momen tingkat, gaya dan momen elem struktur yang dihasilkan, simpangan antar lantai tingkat yang timbul akibat pengaruh ini yang akan berpengaruh pada koefisien stabilitas $(\theta)$ sebagai berikut :

$$
\theta=\frac{p_{x} \Delta I_{e}}{V_{x} h_{s x} C_{d}}
$$


Perhitungan $V_{x}$ berdasarkan SNI 17262012 pasal 7.8.1 sebagai berikut :

$$
\begin{gathered}
V=C_{s} W \\
V=\frac{S_{D S}}{\left(\frac{R}{I_{e}}\right)} W
\end{gathered}
$$

\section{METODE PENELITIAN}

Metode perhitungan yang digunakan dalam analisis ini adalah metode kuantitatif, yaitu melakukan perhitungan struktur atas bangunan agar mendapatkan struktur yang kuat menerima beban yang terjadi. Pembebanan sesuai dengan SNI-1727-2013 tentang Beban Minimum untuk Perencanaan Bangunan Gedung dan Struktur Lain. Analisis gaya dalam permodelan struktur menggunakan software CSI Bridge. Gaya dalam hasil perhitungan program digunakan sebagai alat bantu dalam menganalisa momen yang terjadi akibat adanya pembebanan.

Lokasi tempat penelitian berada pada Stasiun MRT (mass rapid transit) Blok M Jakarta Selatan. Dengan berfokus pada jalur rel tengah seperti gambar 1 dan gambar 2

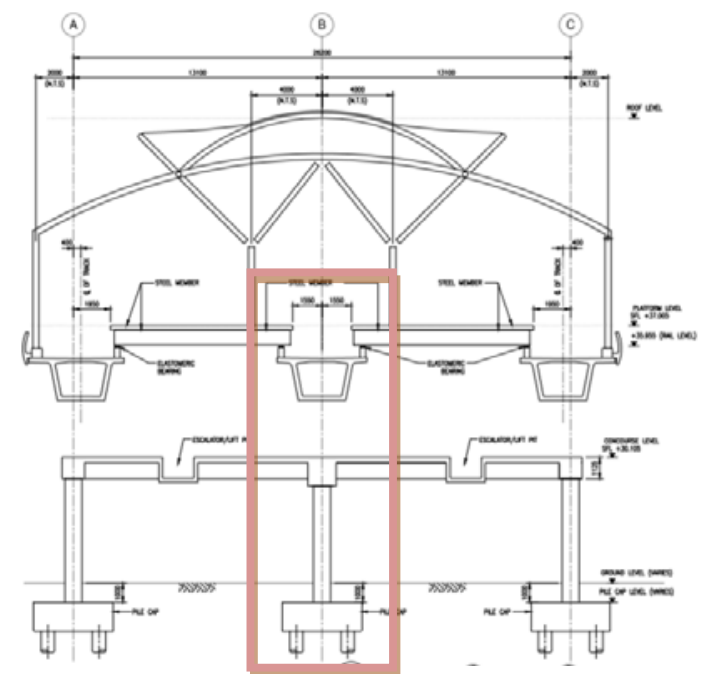

Gambar 1 Potongan Stasiun MRT Blok M

(Sumber : Data MRT)
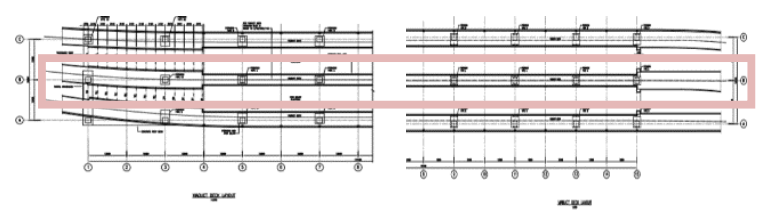

Gambar 2 Denah Balok Kolom

(Sumber : Data MRT)

\section{Pembebanan \\ Spesifikasi Beton}

$\begin{array}{ll}\text { Mutu beton } & : \text { C32/40 } \\ \text { Fc Beton } & : 40 \mathrm{MPa} \\ \mathrm{EC} & : 30094,6839159344 \mathrm{MPa} \\ \mathrm{U} & : 0,2\end{array}$

Modulus geser : $12539,452 \mathrm{MPa}$

$\mathrm{fci}^{\prime}=0,80 \times f \mathrm{c}^{\prime}: 32 \mathrm{MPa}$

Tegangan ijin beton saat penarikan:

- Tekanan ijin tekan : 0,55 $\times f c i^{\prime}=17,6 \mathrm{MPa}$

- Tekanan ijin tarik : $0,80 \times \sqrt{f c i^{\prime}}=4,525 \mathrm{MPa}$

Tegangan ijin beton keadaan akhir :

- Tegangan ijin tekan : $0,40 \times f c^{\prime}=12,8 \mathrm{MPa}$

- Tegangan ijin tarik : $0,60 \times \sqrt{f c^{\prime}}=2,828 \mathrm{MPa}$

\section{Spesifikasi Baja Prategang}

Tabel 2 Standar VSL

DATA STRANDS CABLE - STANDAR VSL

Jenis strands $\quad$ Uncoated 7 wire super strands ASTM A-416 grade 270

\begin{tabular}{lcc} 
Minimum yield stress (Fy) & 421 & $\mathrm{MPa}$ \\
\hline Minimum tnsile stress (Fu) & 1275 & $\mathrm{MPa}$ \\
\hline Diameter nominal strands & 14 & $\mathrm{Mm}$ \\
\hline $\begin{array}{l}\text { Luas tampang nominal satu } \\
\text { strands }\end{array}$ & 150 & $\mathrm{~mm}^{2}$ \\
\hline Modulus elastisitas & 200000 & $\mathrm{~N} / \mathrm{mm}^{2}$ \\
\hline Gaya tendon & 5301000 & $\mathrm{~N}$ \\
\hline Tipe dongkrak & VSL 19 & \\
\hline (Sumber : Data MRT) & &
\end{tabular}

(Sumber : Data MRT)

\section{Berat Sendiri (MS)}

Berat sendiri adalah berat bahan dan bagian jembatan yang merupakan elemen struktural, ditambah elemen non-struktural yang dipikulnya dan bersifat tetap. Berat sendiri dihitung sebagai berikut

Tabel 3 Berat sendiri

\begin{tabular}{lllc}
\hline No. & \multicolumn{1}{c}{$\begin{array}{c}\text { Jenis berat sendiri } \\
\text { konstruksi }\end{array}$} & Satuan & Berat \\
\hline 1 & Box girder prestress & $\mathrm{KN} / \mathrm{m}$ & 159,635 \\
\hline 2 & Diafragma & $\mathrm{KN} / \mathrm{m}$ & 3,840 \\
\hline & $\begin{array}{l}\text { Total berat sendiri, } \\
\text { Q }\end{array}$ & $\mathrm{KN} / \mathrm{m}$ & 163,475 \\
& & \\
\hline
\end{tabular}

\section{Beban Mati Tambahan (MA)}

Beban mati tambahan (superimposed dead load), adalah berat seluruh badan yang menimbulkan suatu beban pada girder jembatan yang merupakan elemen non-struktural, dan mungkin besarnya berubah selama umur jembatan.

Tabel 4 Beban SIDL (superimposed dead load)

\begin{tabular}{lllc}
\hline No. & $\begin{array}{c}\text { Jenis berat sendiri } \\
\text { konstruksi }\end{array}$ & Satuan & Berat \\
\hline 1 & Beban rel & $\mathrm{KN} / \mathrm{m}$ & 5.37405 \\
\hline 2 & $\begin{array}{l}\text { Beban relling untuk } \\
\text { peron }\end{array}$ & $\mathrm{KN} / \mathrm{m}$ & 1.1508 \\
\hline 3 & Beban atap & $\mathrm{KN} / \mathrm{m}$ & 144 \\
\hline
\end{tabular}




\begin{tabular}{cccc} 
No. & $\begin{array}{c}\text { Jenis berat sendiri } \\
\text { konstruksi }\end{array}$ & Satuan & Berat \\
& Total berat SIDL, $\mathrm{Q}_{\mathrm{ms}}$ & $\mathrm{KN} / \mathrm{m}$ & 151,43 \\
\hline
\end{tabular}

Beban Lajur "D" (TD)

Beban lajur " $D$ " terdiri dari beban terbagi merata (Uniformly Distributed Load), UDL dan beban garis (Knife Edge Load).

- Panjang bentang

$: 109,95 \mathrm{~m}$

- Lebar jalur

: $8,10 \mathrm{~m}$

- Beban merata

$: 5,728 \mathrm{kN} / \mathrm{m}$

- Beban merata box girder

: $38,949 \mathrm{kN} / \mathrm{m}$

- Beban garis

: $49 \mathrm{kN} / \mathrm{m}$

- Beban terpusat box girder

: 466,48 kN

\section{Beban Angin (EW)}

Beban garis merata tambahan arah horisontal pada permukaan lantai jembatan akibat angin yang meniup kendaraan di atas lantai jembatan yaitu $1,764 \mathrm{kN} / \mathrm{m}$ dan untuk bidang vertikal yang ditiup angin merupakan bidang samping kendaraan yaitu $2,891 \mathrm{kN} / \mathrm{m}$

\section{Beban Gempa (EQ)}

Analisis beban gempa dilakukan dengan cara dinamik respon spektrum dan didasarkan pada SNI 1726-2012 di tinjau berdasarkan 3 jenis gempa

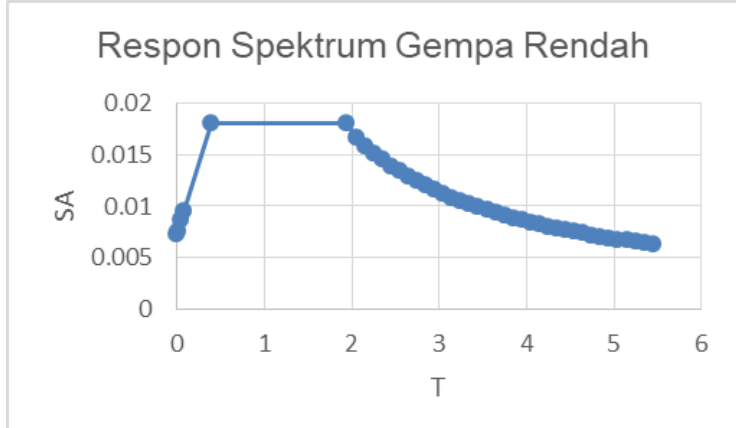

Gambar 3 Grafik respons spectrum

Parameter Respons Spektrum
SMS(g): 0.026
T0 :0.390
SM1 $(g): 0.052$
PGA :0,007
$\operatorname{SDS}(g): 0.018$
SS :0,017
SD1(g) :0.034
S1 :0,027
$\mathrm{T}: 0.540$

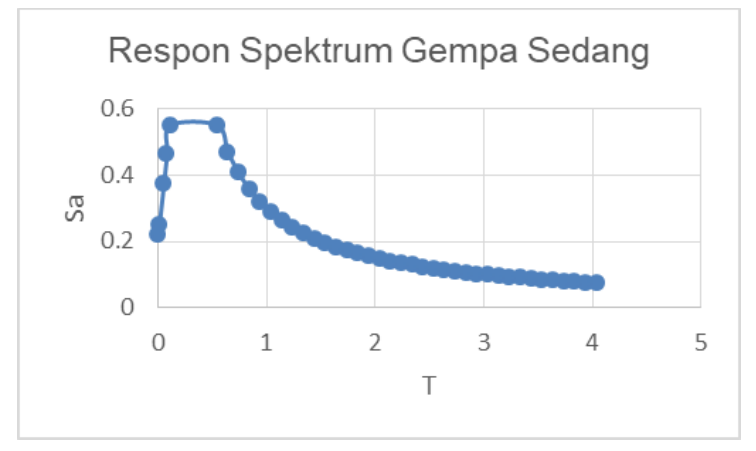

Gambar 4 Grafik respons spektrum
Parameter Respons Spektrum

$\begin{array}{lll}\text { SMS(g) }: 0.825 & \text { T0 } & : 0.169 \\ \text { SM1(g) }: 0.450 & \text { PGA } & : 0,44 \\ \text { SDS(g) }: 0.550 & \text { SS } & : 0,55 \\ \text { SD1(g) }: 0.300 & \text { S1 } & : 0,30 \\ \text { T }: 0.540 & & \end{array}$

\section{Respon Spektrum Gempa Tinggi}

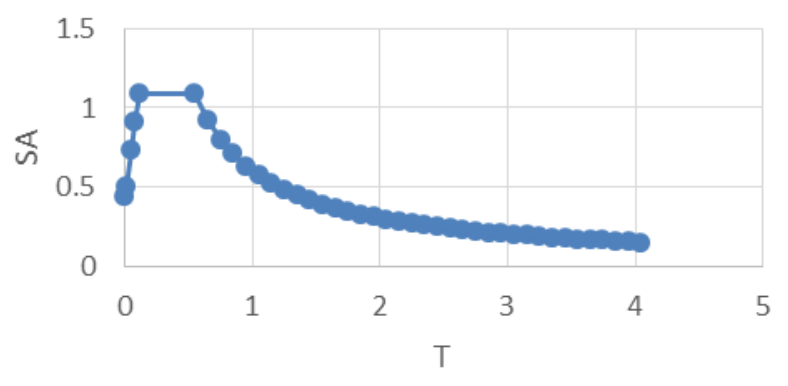

Gambar 5 Grafik respons spektrum

Parameter Respons Spektrum

$\begin{array}{rll}\operatorname{SMS}(g): 1,637 & \text { T0 } & : 0.110 \\ \operatorname{SM} 1(g): 0.900 & \text { PGA } & : 0.643 \\ \operatorname{SDS}(g): 1,091 & \text { SS } & : 1.637 \\ \operatorname{SD1}(g): 0.600 & \text { S1 } & : 0.600 \\ \text { T } \quad: 0.55 & & \end{array}$

Kombinasi Beban (Load Combination)

Kombinasi pembebanan yang akan dilakukan pada analisis kali ini yaitu menggunakan SNI.

Tabel 5. Kombinasi Beban SNI

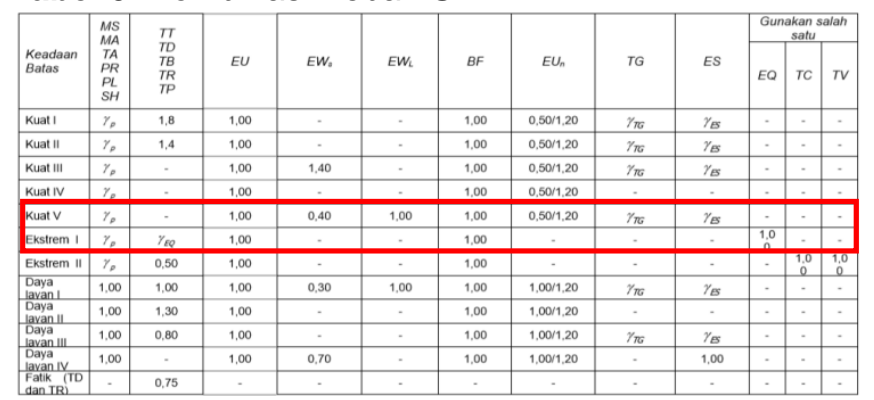

Sumber: SNI 1726-2012

\section{HASIL DAN PEMBAHASAN}

\section{Hasil Pemodelan}

Berikut merupakan hasil dari pemodelan jembatan box girder pada program CSI Bridge. 


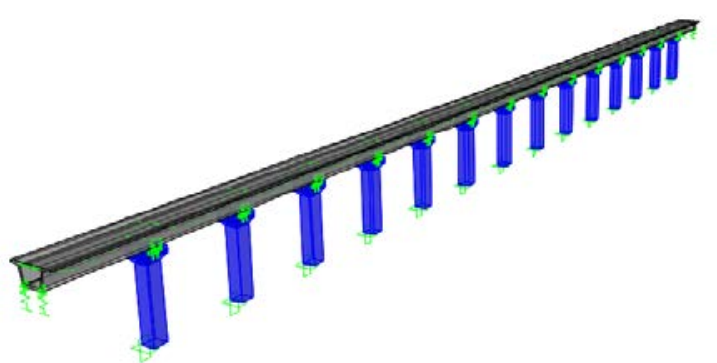

Gambar 6. Pemodelan Struktur dengan CSI Bridge.

\section{Evaluasi Hasil Analisis Perilaku Struktur}

Dalam mencapai tujuan untuk mengetahui perbedaan dan perubahan perilaku bangunan, dari data rekapitulasi momen yang terjadi, pada permodelan dengan menggunakan sistem struktur pilar dan girder dilihat dari faktor-faktor perilaku seperti momen, gaya geser, displacement, defleksi dan pengaruh $\mathrm{P}-\Delta$. Maka dilakukan evaluasi hasil analisis permodelan yang dilakukan di software CSI Bridge.

\section{Analisis Momen}

Momen yang terjadi pada pemodelan struktur dapat dilihat pada gambar grafik 7 di bawah ini.

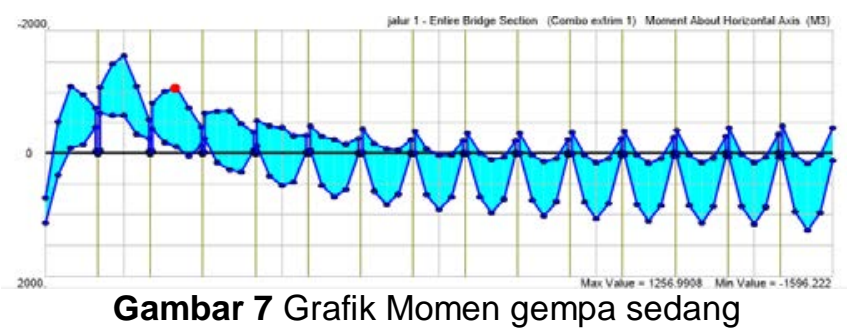

Dari data rekapitulasi momen yang terjadi, pada pemodelan struktur dengan menggunakan perhitungan SNI Jembatan maka didapatkan grafik seperti pada di atas. Berat struktur merupakan salah satu faktor yang mempengaruhi nilai momen, semakin berat struktur maka akan semakin besar pula nilai momen dari struktur tersebut. Berikut tabel 6 nilai momen maksimum yang terjadi pada pemodelan struktur jembatan box girder

Tabel 6 Momen

\begin{tabular}{cccccccc}
\hline \multirow{2}{*}{ Momen } & & \multicolumn{2}{c}{ Gempa Sedang } & \multicolumn{2}{c}{ Gempa Rendah } & \multicolumn{2}{c}{ Gempa Tinggi } \\
\cline { 2 - 8 } & & $\begin{array}{c}\text { Momen (Kgf- } \\
\text { m) }\end{array}$ & $\begin{array}{c}\text { Momen } \\
(\text { Ton-m) }\end{array}$ & $\begin{array}{c}\text { Momen (Kgf- } \\
\text { m) }\end{array}$ & $\begin{array}{c}\text { Momen (Ton- } \\
\text { m) }\end{array}$ & $\begin{array}{c}\text { Momen } \\
\text { (Kgf-m) }\end{array}$ & $\begin{array}{c}\text { Momen } \\
\text { (Ton-m) }\end{array}$ \\
\hline \multirow{2}{*}{ Maksimum } & + & 1256991 & 1256,991 & 1179459.2 & 1179.4592 & 1334841.7 & 1334,8717 \\
\cline { 2 - 8 } & - & 1596227 & 1596,22 & 1525112 & 1525.112 & 1667630 & 1667,63 \\
\hline Minimum & + & 0,00023 & $2,3 \times 10^{-7}$ & 0,00018 & $1,8 \times 10^{-7}$ & 0,00046 & $4,6 \times 10^{-7}$ \\
& - & 0,00023 & $2,3 \times 10^{-1}$ & 0,00018 & $1,8 \times 10^{-1}$ & 0,00046 & $4,6 \times 10^{-1}$ \\
\hline
\end{tabular}

Dari tabel 6 di atas dapat dilihat bahwa nilai momen maksimum arah positif $(+)$ dari permodelan struktur dengan box girder didapatkan pada gempa skala tinggi yaitu 1334,8717 ton.m sedangkan arah negatifnya (-) didapatkan pada gempa skala tinggi 1667,63 ton $\mathrm{m}$, untuk momen minimum arah positif (+) nilai dari gempa rendah dipemodelan analisis yaitu 1,8×10-7 ton.m sedangkan arah negatif (-) didapatkan pada gempa skala rendah yaitu 1,8×10-7 ton.m .momen merupakan suatu persamaan diferensian berpangkat dua terhadap beban sehingga memiliki grafik fungsi parabola Maka dari hasil analisis di atas telah membuktikan bahwa momen yang terbesar berada pada batang lapangan disetiap segmen yang telah dianalisis dan membentuk grafik parabola disetiap segmennya.

\section{Analisis Gaya Geser}

Gaya geser dari pemodelan dapat dilihat pada gambar grafik 8 berikut.

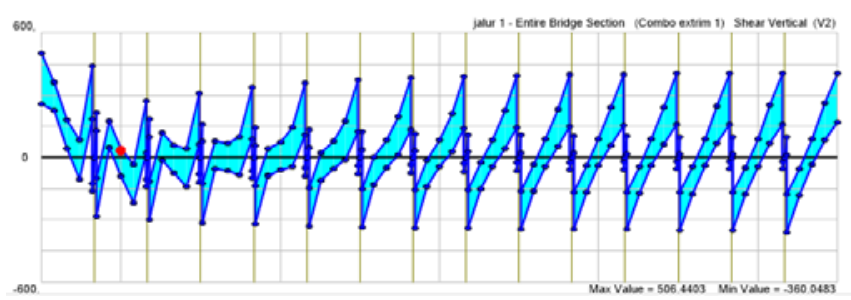

Gambar 8. Grafik Gaya Geser

Dari data rekapitulasi nilai gaya geser yang terjadi, pada pemodelan struktur dengan menggunakan perhitungan SNI Jembatan maka didapatkan grafik seperti pada di atas.

Tabel 7. Gaya Geser

\begin{tabular}{cccccccc}
\hline \multirow{2}{*}{ Gaya Geser } & \multicolumn{2}{c}{ Gempa Sedang } & \multicolumn{2}{c}{ Gempa Rendah } & \multicolumn{2}{c}{ Gempa Tinggi } \\
\cline { 2 - 7 } & & $(\mathrm{Kg})$ & $(\mathrm{Ton})$ & $(\mathrm{Kg})$ & $(\mathrm{Ton})$ & $(\mathrm{Kg})$ & (Ton) \\
\hline Maksimum & + & 506440,3 & 506.4403 & 505054,8 & 505,0548 & 507831.4 & 507,8314 \\
\hline Minimum & - & 36004 & 360.0483 & 358871,0 & 358,8708 & 361228,0 & 361,2279 \\
\hline & - & 0,00036 & $3,6 \times 10^{-1}$ & 0,00029 & $2,9 \times 10^{-1}$ & 0,00072 & $7,2 \times 10^{-1}$ \\
\hline & - & 0,00036 & $3,6 \times 10^{-1}$ & 0,00029 & $2,9 \times 10^{-1}$ & 0,00072 & $7,2 \times 10^{-1}$ \\
\hline
\end{tabular}

Nilai gaya geser maksimum untuk arah positif $(+)$ yaitu 507,83 ton digempa skala tinggi sedangkan untuk arah negatif (-) yaitu 361,2279 ton digempa skala tinggi.
Untuk gaya geser minimum untuk arah positif (+) yaitu 2,9x10-7 digempa skala rendah sedangkan untuk arah negatif (-) yaitu 2,9×10-7 digempa skala rendah. Berdasarkan tabel 4.23 dari hasil pemodelan dapat 
disimpulkan bahwa gaya geser berbanding lurus dengan berat struktur sama seperti momen. Hal tersebut dapat dibuktikan dari rumus gaya geser yang merupakan turunan dari momen, dimana besarnya nilai gaya geser dipengaruhi oleh seluruh beban-beban yang bekerja pada struktur dan telah terbukti oleh analisis ini bahwa nilai gaya geser disetiap tumpuan lebih besar dibandingkan dengan dilapangan.

\section{Analisis Displacement}

Data rekapitulasi displacement pada pemodelan struktur jembatan box girder dapat dilihat pada tabel 8 , tabel 9 , tabel 10 berikut.

Tabel 8 Displacement Arah X

\begin{tabular}{cccc} 
Segmen & $\begin{array}{c}\text { gempa } \\
\text { tinggi } \\
(\mathrm{mm})\end{array}$ & $\begin{array}{c}\text { gempa } \\
\text { lemah } \\
(\mathrm{mm})\end{array}$ & $\begin{array}{c}\text { gempa } \\
\text { Sedang } \\
(\mathrm{mm})\end{array}$ \\
\hline 1 & $-0,7531$ & $-0,53539$ & $-0,64402$ \\
\hline 2 & $-3,78461$ & $-3,18939$ & $-3,48638$ \\
\hline 3 & $-5,81086$ & $-5,08677$ & $-5,34306$ \\
\hline 4 & $-7,03657$ & $-5,9228$ & $-6,41965$ \\
\hline 5 & $-7,67301$ & $-6,24572$ & $-6,93312$ \\
\hline 6 & $-7,6569$ & $-6,2169$ & $-7,04527$ \\
\hline 7 & $-7,41315$ & $-5,95559$ & $-6,87698$ \\
\hline 8 & $-7,41315$ & $-5,53887$ & $-6,50564$ \\
\hline 9 & $-6,87118$ & $-5,01779$ & $-5,98399$ \\
\hline 10 & $-6,07645$ & $-4,42377$ & $-5,34657$ \\
\hline 11 & $-5,23448$ & $-3,7716$ & $-4,61524$ \\
\hline 12 & $-4,27583$ & $-3,06325$ & $-3,80316$ \\
\hline 13 & $-3,19825$ & $-2,28785$ & $-2,93211$ \\
\hline 14 & $-1,98495$ & $-1,67349$ & $-1,96312$ \\
\hline 15 & $-0,72535$ & $-0,89789$ & $-1,00043$ \\
\hline
\end{tabular}

* negatif (-) hanya menunjukan arah

Tabel 9 Displacement Arah Y

\begin{tabular}{cccc}
\hline Segmen & $\begin{array}{c}\text { Gempa } \\
\text { tinggi } \\
(\mathrm{mm})\end{array}$ & $\begin{array}{c}\text { gempa } \\
\text { lemah } \\
(\mathrm{mm})\end{array}$ & $\begin{array}{c}\text { gempa } \\
\text { Sedang } \\
(\mathrm{mm})\end{array}$ \\
\hline 1 & 1,70973 & 1,43945 & 1,57387 \\
\hline 2 & 8,87021 & 6,8274 & 7,75932 \\
\hline 3 & 15,51334 & 10,78053 & 13,63081 \\
\hline 4 & 20,33178 & 14,31027 & 17,59546 \\
\hline 5 & 23,38523 & 16,21546 & 19,92538 \\
\hline 6 & 26,3771 & 17,2229 & 21,22319 \\
\hline 7 & 26,3771 & 17,41534 & 21,89731 \\
\hline 8 & 26,72869 & 17,48058 & 22,08626 \\
\hline 9 & 26,27663 & 17,39261 & 21,80114 \\
\hline 10 & 25,35747 & 17,10652 & 21,0311 \\
\hline 11 & 23,56474 & 16,43215 & 19,6459 \\
\hline 12 & 20,74775 & 14,99753 & 17,26525 \\
\hline 13 & 16,38841 & 12,27751 & 13,35107 \\
\hline
\end{tabular}

\begin{tabular}{cccc}
\hline Segmen & $\begin{array}{c}\text { Gempa } \\
\text { tinggi } \\
(\mathrm{mm})\end{array}$ & $\begin{array}{c}\text { gempa } \\
\text { lemah } \\
(\mathrm{mm})\end{array}$ & $\begin{array}{c}\text { gempa } \\
\text { Sedang } \\
(\mathrm{mm})\end{array}$ \\
\hline 14 & 10,19669 & 6,81154 & 7,7353 \\
\hline 15 & 3,08957 & 1,41403 & 1,56627 \\
\hline
\end{tabular}

Tabel 10 Displacement Arah Z

\begin{tabular}{cccc}
\hline Segmen & $\begin{array}{c}\text { gempa } \\
\text { tinggi } \\
(\mathrm{mm})\end{array}$ & $\begin{array}{c}\text { gempa } \\
\text { lemah } \\
(\mathrm{mm})\end{array}$ & $\begin{array}{c}\text { gempa } \\
\text { Sedang } \\
(\mathrm{mm})\end{array}$ \\
\hline 1 & $-2,22486$ & $-1,89112$ & $-2,05765$ \\
\hline 2 & $-2,55903$ & $-2,26821$ & $-2,41332$ \\
\hline 3 & $-1,61001$ & $-0,9457$ & $-1,47009$ \\
\hline 4 & $-1,96956$ & $-1,46458$ & $-1,84047$ \\
\hline 5 & $-2,4947$ & $-1,84735$ & $-2,38141$ \\
\hline 6 & $-3,07871$ & $-2,6601$ & $-2,75779$ \\
\hline 7 & $-3,07871$ & $-2,33607$ & $-3,01277$ \\
\hline 8 & $-3,21656$ & $-2,48745$ & $-3,17987$ \\
\hline 9 & $-3,303$ & $-2,59752$ & $-3,29051$ \\
\hline 10 & $-2,70845$ & $-2,67676$ & $-3,39835$ \\
\hline 11 & $-2,77148$ & $-2,73355$ & $-3,48666$ \\
\hline 12 & $-2,85036$ & $-2,77631$ & $-3,55178$ \\
\hline 13 & $-2,9228$ & $-2,80933$ & $-3,59843$ \\
\hline 14 & $-2,9817$ & $-3,50593$ & $-3,62852$ \\
\hline 15 & $-3,0474$ & $-3,28926$ & $-3,45346$ \\
\hline * negatif $(-)$ hanya menunjukan arah &
\end{tabular}

Nilai displacement (perpindahan) arah $\mathrm{X}$ dan arah $\mathrm{Y}$ berbeda-beda diakibatkan jembatan memiliki gaya yang disebabkan oleh getaran akibat gempa yang mempengaruhi perpindahan tersebut. Nilai displacement dibentang awal dan dibentang akhir lebih kecil dibandingkan dengan di tengah bentang, karena bentang awal dan bentang akhir dibuat perletakan sendi dan dianggap sebagai abutment sehingga membuat nilai displacement mengecil.

Nilai displacement (lendutan) arah z memiliki nilai yang cukup konstan karena lendutan yang diakibatkan oleh beban dan getaran gempa yang menimbulkan momen memiliki beban nilai yang sama besar sehingga perubahan lendutan tidak terlalu besar

Dari tabel 8 tabel 9 tabel 10 di atas dapat dilihat dengan displacement maksimum $-5,53887 \mathrm{~mm}$ arah $\mathrm{x}$, $17,48058 \mathrm{~mm}$ arah $\mathrm{y}$, dan $-2,48745 \mathrm{~mm}$ arah $\mathrm{z}$.lendutan izin arah z pada jembatan adalah $\Delta=\frac{\mathrm{L}}{800}=$ $\frac{12,5}{800}$ dengan hasil $\Delta=0,015 \mathrm{~m}=15 \mathrm{~mm}$ maka lendutan baik gempa tinggi, gempa rendah, dan gempa Sedang sudah memenuhi syarat

\section{Pengaruh Defleksi}

Defleksi atau simpangan antar lantai harus dihitung sebagai perbedaan defleksi pada pusat massa jembatan yang ditinjau. 
Tabel 11 Defleksi Arah $\mathrm{x}$

\begin{tabular}{|c|c|c|c|c|c|c|c|c|}
\hline \multirow[t]{2}{*}{$\begin{array}{l}\text { Skala } \\
\text { gempa }\end{array}$} & Tinggi & $\delta_{x e}$ & I & $\mathrm{C}_{\mathrm{d}}$ & $\delta$ & $\Delta$ & $\Delta i z i n$ & $\begin{array}{c}\Delta \leq \\
\Delta i z i n\end{array}$ \\
\hline & (m) & $(\mathrm{mm})$ & & & $(\mathrm{mm})$ & $(\mathrm{mm})$ & $(\mathrm{mm})$ & \\
\hline Gempa & 10,228 & 6,505 & 1,5 & 5,5 & 23,851 & 16,507 & 71,596 & Ok \\
\hline Sedang & 5,114 & 2,003 & 1,5 & 5,5 & 7,344 & 7,344 & 35,798 & Ok \\
\hline Gempa & 10,228 & 7,413 & 1,5 & 5,5 & 27,181 & 19,646 & 71,596 & Ok \\
\hline Tinggi & 5,114 & 2,055 & 1,5 & 5,5 & 7,535 & 7,535 & 35,798 & Ok \\
\hline Gempa & 10,228 & 5,538 & 1,5 & 5,5 & 20,306 & 13,4126667 & 71,596 & Ok \\
\hline Rendah & 5,114 & 1,88 & 1,5 & 5,5 & 6,893333 & 6,89333333 & 35,798 & Ok \\
\hline
\end{tabular}

Tabel 12 Defleksi Arah Y

\begin{tabular}{ccccccccc} 
Skala & Tinggi & $\delta_{\text {xe }}$ & $\mathrm{I}$ & $\mathrm{C}_{\mathrm{d}}$ & $\delta$ & $\Delta$ & $\Delta \boldsymbol{i z i n}$ & $\Delta \leq \Delta \boldsymbol{i z i n}$ \\
gempa & & & & & & & & \\
\cline { 2 - 9 } & $(\mathrm{m})$ & $(\mathrm{mm})$ & & & $(\mathrm{mm})$ & $(\mathrm{mm})$ & $(\mathrm{mm})$ & \\
Gempa & 10,228 & 13,41 & 1,5 & 5,5 & 49,17 & 32,266 & 71,596 & Ok \\
\cline { 2 - 9 } Sedang & 5,114 & 4,61 & 1,5 & 5,5 & 16,903 & 16,903 & 35,798 & Ok \\
\hline Gempa & 10,228 & 16,61 & 1,5 & 5,5 & 60,903 & 37,767 & 71,596 & Ok \\
\hline Tinggi & 5,114 & 6,31 & 1,5 & 5,5 & 23,137 & 23,137 & 35,798 & Ok \\
\hline Gempa & 10,228 & 12,87 & 1,5 & 5,5 & 47,19 & 31,386 & 71,596 & Ok \\
Rendah & 5,114 & 4,31 & 1,5 & 5,5 & 15,803 & 15,803 & 35,798 & OK
\end{tabular}

Defleksi semua permodelan sudah memenuhi izin dengan $\Delta$ izin $=0,007 \mathrm{hx}$ berdasarkan SNI 17262012 pasal 7.12.1. dan besarnya defleksi ditentukan oleh besarnya faktor resiko (Ix) suatu gempa dan pergeseran setiap lantai serta pergerakan displacement arah $\mathrm{x}$ di masing masing gempa.

\section{Pengaruh $\mathrm{P}-\Delta$}

Hasil dari perhitungan perbandingan koefisien stabilitas antar gempa rendah dan tinggi sebagai berikut :

Tabel 13 Koefisien Stabilitas Arah X

\begin{tabular}{|c|c|c|c|c|c|c|c|c|c|}
\hline \multirow{2}{*}{$\begin{array}{c}\text { Gempa } \\
\text { skala }\end{array}$} & \multirow[t]{2}{*}{ tinggi } & \multirow[t]{2}{*}{$\Delta$} & \multirow[t]{2}{*}{$\mathrm{cd}$} & \multirow[t]{2}{*}{ le } & \multirow[t]{2}{*}{$\mathrm{P}$} & \multirow[t]{2}{*}{ V } & \multirow[t]{2}{*}{$\theta$} & \multirow[t]{2}{*}{$\theta \max$} & \multirow{2}{*}{$\begin{array}{c}\theta<0,1 \\
\theta<\max \end{array}$} \\
\hline & & & & & & & & & \\
\hline gempa & 10228 & 16,5073 & 5,5 & 1,5 & 44130,2 & 4550,922 & 0,004 & 0,091 & ok \\
\hline Sedang & 5114 & 7,34433 & 5,5 & 1,5 & 44130,2 & 4550,922 & 0,004 & 0,091 & ok \\
\hline \multirow{2}{*}{$\begin{array}{c}\text { gempa } \\
\text { tinggi }\end{array}$} & 10228 & 19,646 & 5,5 & 1,5 & 44130,2 & 9027,374 & 0,003 & 0,091 & ok \\
\hline & 5114 & 7,535 & 5,5 & 1,5 & 44130,2 & 9027,374 & 0,002 & 0,091 & ok \\
\hline \multirow{2}{*}{$\begin{array}{l}\text { gempa } \\
\text { rendah }\end{array}$} & 10228 & 13,4127 & 5,5 & 1,5 & 44130,2 & 1489,393 & 0,011 & 0,091 & ok \\
\hline & 5114 & 6,89333 & 5,5 & 1,5 & 44130,2 & 1489,393 & 0,011 & 0,091 & ok \\
\hline
\end{tabular}

Tabel 14 Koefisien Stabilitas Arah $Y$

\begin{tabular}{cccccccccc}
$\begin{array}{c}\text { Gempa } \\
\text { skala }\end{array}$ & tinggi & $\Delta$ & cd & le & $P$ & $V$ & $\theta$ & $\theta \max$ & $\theta<0,1$ \\
\hline $\begin{array}{c}\text { gempa } \\
\text { Sedang }\end{array}$ & 10228 & 32,2667 & 5,5 & 1,5 & 44130,2 & $\begin{array}{c}4550,92 \\
2\end{array}$ & 0,008 & 0,091 & ok \\
\cline { 2 - 10 } & 5114 & 16,9033 & 5,5 & 1,5 & 44130,2 & 4550,922 & 0,009 & 0,091 & ok \\
\hline gempa & 10228 & 37,7667 & 5,5 & 1,5 & 44130,2 & 9027,374 & 0,005 & 0,091 & ok \\
\cline { 2 - 10 } tinggi & 5114 & 23,1367 & 5,5 & 1,5 & 44130,2 & 9027,374 & 0,006 & 0,091 & ok \\
\hline $\begin{array}{c}\text { gempa } \\
\text { rendah }\end{array}$ & 10228 & 31,3867 & 5,5 & 1,5 & 44130,2 & 1489,393 & 0,025 & 0,091 & ok \\
\hline
\end{tabular}

Data di atas adalah nilai koefisien stabilitas yang diakibatkan oleh pengaruh $\mathrm{P}-. \Delta$. nilai sudut yang di hasilkan dari pengaruh $\mathrm{P}-. \Delta$ sudah memenuhi syarat yang diizin kan dengan $\theta \max =0,5 /\left(\beta C \_d\right) \leq 0,25$ yang berdasarkan SNI 1726 2012. Besarnya stabilitas antara gempa diakibatkan oleh $\Delta$ yang dipengaruhi oleh faktor reduksi gempa (Ix ) yang berbeda beda nilainya.

\section{KESIMPULAN}

Dalam analisis ini mengevaluasi tentang momen, gaya geser, displacement, simpangan antar lantai , koefisien stabilitas . dengan perbandingan antar gempa lemah dan gempa tinggi serta gempa sedang yang nilainya sudah memenuhi syarat izin dan sudah memenuhi syarat ketentuan gempa SNI 17262012 


\section{REFERENSI}

Badan Standarisasi Nasional. (2008). standar perencanaan ketahanan gempa untuk jembatan, SNI 2833 2008, Jakarta.

Badan Standarisasi Nasional. (2012). Tata cara perencanaan ketahanan gempa untuk struktur bangunan gedung dan non gedung, SNI 1726 2012. Jakarta.

Badan Standarisasi Nasional. (2013). Beban minimum untuk perencanaan struktur bangunan gedung dan struktur lain, SNI -17272013,Jakarta.

Badan Standarisasi Nasional. (2016.) Pembebanan untuk jembatan, SNI 1725 2016, Jakarta.

Computer \& struktur, inc. (2017). CSI BRIDGE 2017, amerika

Muntohar, agus setyo. (2007). Jembatan, Yogyakarta.

Muslim fadhilah. (2012). kajian pengaruh gempa terhadap perilaku jembatan kabel suramadu selama tahap konstruksi dengan analisis riwayat waktu,skripsi, depok, universitas indonesia

Nawy, G. Adward. (1998). Beton Bertulang, Biro Penerbit, PT. Refika Aditama.

Nugroho, budi. (2016). perancangan jembatan , samarinda.

Sudarmoko. (1996). Perencanaan dan Analisis Kolom Beton Bertulang, Biro Penerbit, Yogyakarta. 